\title{
Comparative Analysis of the Implementation of Life Skill Education Management in Students With Disability Between Public Special School and Private Special Schools
}

\author{
Johar Permana*, Eka Prihatin, Endang Rochyadi \\ Postgraduate School \\ Universitas Pendidikan Indonesia \\ Bandung, Indonesia \\ *permanajohar@upi.edu
}

\author{
Liah Siti Syarifah \\ Islamic Education Management Study Program \\ STAI Syamsul 'Ulum Sukabumi \\ Sukabumi, Indonesia
}

\begin{abstract}
The implementation of life skills management carried out by schools for students with disabilities has a difference between one school and another, in this article we will analyze the comparison of the implementation of life skill management for students with disabilities in State Special Schools and private Special Schools. The study was carried out at State Special Schools and private Special Schools in Sukabumi District with 10 respondents for each school consisting of the principal, the vice principal of the curriculum section, teacher and school committee. The approach taken was a mixed method. The questionnaire was used to see the uniformity of opinion of the academic community in each school and to deepen the research data conducted interviews, observations and documentation studies in answering how to analyze the implementation of life skills education management in State Special Schools and private Special Schools. . The results showed that there were differences in life skills management between SLBN and SLBS, another finding was disagreement of opinions among the academic community in each school regarding life skills education management through its principles, namely planning, organizing, implementing and evaluating. The recommendation put forward that all academics must have the same understanding regarding life skills education management.
\end{abstract}

Keywords—analysis, disability, life skill, management

\section{RESEARCH GAP}

Life skills management for students with disability is the main focus to prepare them to enter the workplace and the business world, thus it will erase the understanding that students with disability are reported as a burden to others and their families [1]. With regard to this issue, all special schools use the same curriculum related to life skills education, yet this is not sufficient to prepare graduates who are financially independent, this has spurred life skills education management model favoured by their schools by using various approaches to bridge schools with. The business world and industrial world
(DUDI) [2]. Within its implementation, life skills management requires the same viewpoint and understanding from the entire academic communities, thus the objectives can be achieved effectively and efficiently and possess high quality values [3].

In this regard, life skills education is education to provide basic provisions for students regardless the values of daily life, and in turns, they will be able and have skills in solving life problems and surviving in the face of every change to run their living in the near future. Life skills education for students with disability requires specialized services, supports and extraordinary teacher where the management must be conducted professionally. Life skills management for students with disability uses an inclusive and integrated approaches. It is stated to be an integration because the concept of adding something to an existing problem can be seen in Figure 1 as follows:

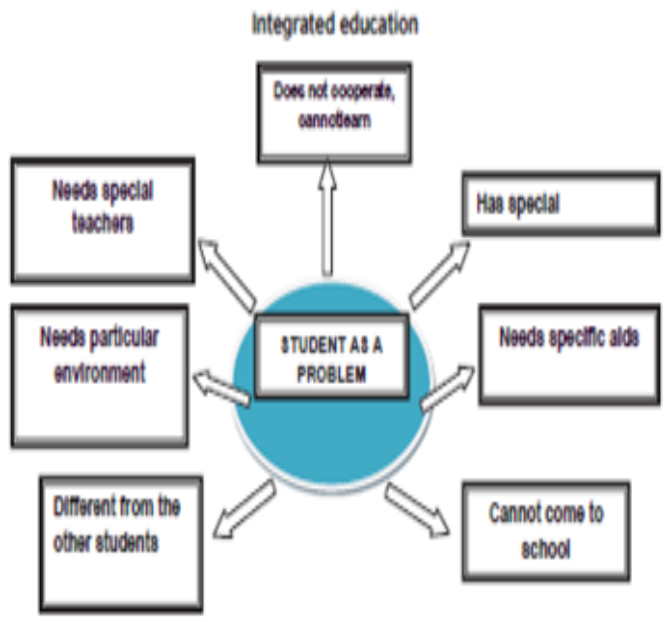

Fig. 1. Integrated Education (EENET, 1998, 1DDC, Seminar on Inclusive Education, Agra, India). 
Whereas inclusion is comprehensive in other words contained on it, and therefore the approach is considerably to change and adapt the needs of each students, can be seen in Figure 2 as follows:

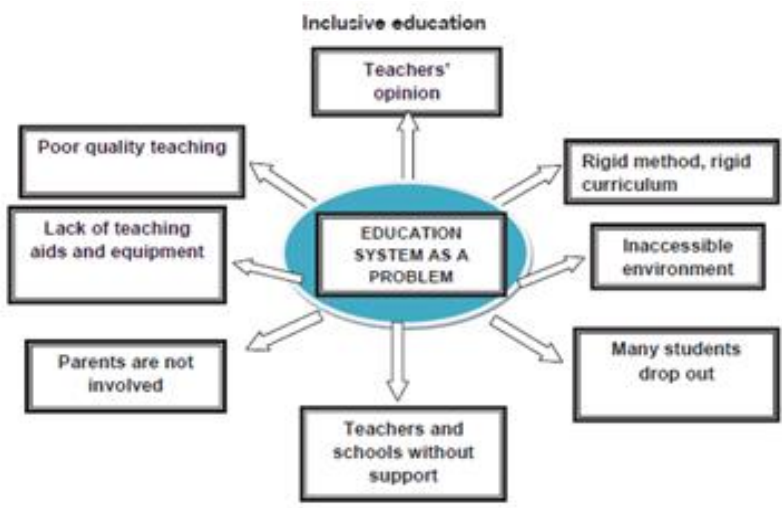

Fig. 2. Inclusive Education (EENET, 1998, IDDC, Seminar on Inclusive Education, Agra, India).

Hence, the principles of inclusive education are (1) the principle of social acceptance and support; (2) the principle of early intervention and rehabilitation; (3) the principle of developing functional capabilities; (4) the principle of stimulation and compensation. In an effort to address such situation, the research question reveals how the differences in life skills education management are more focused on the vocational education for students with disability carried out by public special school and private special schools.

There are many prior studies related to such issues, including ho researched disability briefing to encourage them to have their own care, where they felt that the life skills education program had a positive impact on equipping them, besides Afsaneh et al. related to life skills in time management, self-efficacy and competencies that students with disability must have [4]. And Donnellan and Mathews suggests that life skills are very notable for the success of the transition to adulthood from child dependence to adult independence [5].

With regard to this issue, the novelty of this research on life skills management for students with disability which is focused on skills that can foster their life independence, where in addition to be integrated in the curriculum there is also an inclusive side with the addition of skills trained to the abilities and needs of each student. And therefore, the options for skills development become more diverse through internships, training and programs designed by schools [6].

\section{METHODOLOGY}

This research-based paper uses mixed methods, where a quantitative approach uses a questionnaire to capture the similarity of viewpoints from the data and information of respondents related to planning, organizing, implementing and monitoring life skills education carried out by two schools,
Public Special School (SLBN) and Private Special School (SLBS) in Sukabumi Regency (See Figure 3).

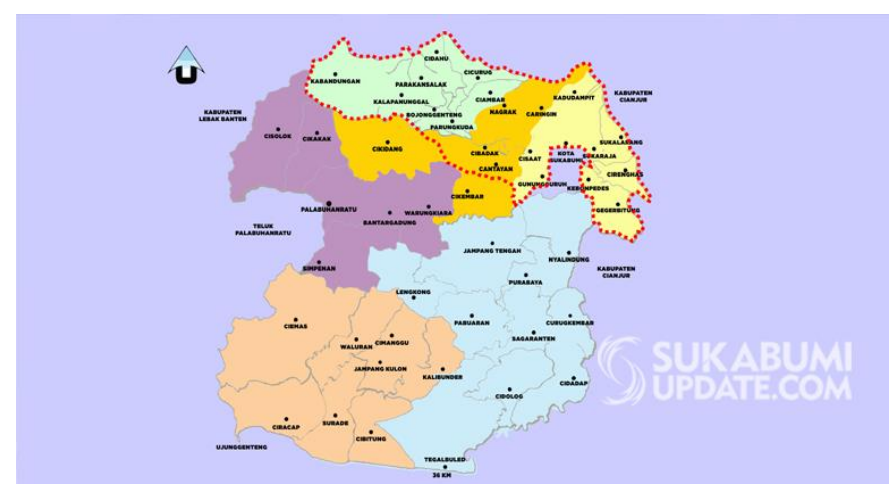

Fig. 3. Sukabumi Regency.

To address these issues, the qualitative approach uses interviews, observations and documentation studies as complement and to re-check data and information received from the quantitative approach. The respondents for each school were 10 people consisting of the principal, vice principal, teachers and school committees.

\section{RESULTS AND DISCUSSION}

Before you begin to format your paper, first write and save the content as a separate text file. Keep your text and graphic files separate until after the text has been formatted and styled. Do not use hard tabs, and limit use of hard returns to only one return at the end of a paragraph. Do not add any kind of pagination anywhere in the paper. Do not number text headsthe template will do that for you. Due to the strict of international publication standard (Atlantis Press), please set your full paper not over 6 pages. If not meet the standard, your full paper may be not published, because of it will be rejected from publisher.

Overall, the life skills management carried out in special schools both public and private, has been categorized satisfactory, nevertheless there are findings that distinguish it, namely the SLBN stipulates a policy that schools collaborate with local governments to hold skills training and build synergy among the schools, government and Business World and Industrial World (DUDI) where the government acts as a connector between the school and DUDI. In its implementation, the government encourages a lot about changes where graduates are absorbed in DUDI, the only matter is afterwards they have problems where graduates express that they resign from their jobs, the most prominent reason is the difficulty of socializing and communicating with other employees (who are not with disability).

Meanwhile, in private special school, the policy of transferring students with disability to public schools is carried out through an assessment conducted by the teacher by observing students while participating in an affective learning, psychomotor and cognitive spheres. With the preparation and 
assessment strategies carried out, many students have transferred to public schools and monitored their performance is very satisfying, in the sense that they are able to follow the learning process thoroughly.
Moreover, the comparison in the implementation of life skills management between SLBN and SLBS in Sukabumi Regency is as follows (See Table 1) and the next comparison between SLBN and SLBS is as follows (See Table 2):

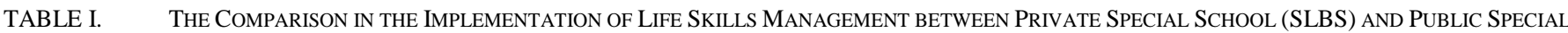
SCHOOL (SLBN)

\begin{tabular}{|c|c|c|}
\hline Question & Private Special School (SLBS) & Public Special School (SLBN) \\
\hline \multicolumn{3}{|c|}{ Planning } \\
\hline $\begin{array}{l}\text { Schools formulate a curriculum with a "self-reliance } \\
\text { program" oriented towards the national curriculum }\end{array}$ & $\begin{array}{l}70 \% \text { of respondents stated that it was correct and } \\
30 \% \text { stated that it was very correct }\end{array}$ & $\begin{array}{l}60 \% \text { of respondents stated that it was } \\
\text { correct and } 40 \% \text { stated that it was very } \\
\text { correct }\end{array}$ \\
\hline $\begin{array}{l}\text { The independence program (Permendikbud No.157 of } 2014 \\
\text { concerning curriculum for students with disability) is } \\
\text { provided as reinforcement for students with special needs to } \\
\text { equip for independent living, not to depend on others, and } \\
\text { to prepare for workplace. }\end{array}$ & $\begin{array}{l}80 \% \text { of respondents said it was appropriate and } \\
20 \% \text { said it was very appropriate. }\end{array}$ & $\begin{array}{l}80 \% \text { of respondents said it was appropriate } \\
\text { and } 20 \% \text { said it was very appropriate. }\end{array}$ \\
\hline $\begin{array}{l}\text { In the planning phase of the skills program (life skills), the } \\
\text { school conducts an "assessment" focused on analyzing the } \\
\text { gap between the skills curriculum, the needs of the } \\
\text { workplace and the conditions of students with disability. }\end{array}$ & $\begin{array}{l}15 \% \text { of respondents said ever, } 10 \% \text { said often and } \\
75 \% \text { said always. }\end{array}$ & $\begin{array}{l}70 \% \text { of respondents said often and } 20 \% \\
\text { said always, and } 10 \% \text { said ever }\end{array}$ \\
\hline $\begin{array}{l}\text { The types of skills (life skills) that are chosen to be } \\
\text { developed by schools are based on the "assessment" in the } \\
\text { program planning phase }\end{array}$ & $\begin{array}{l}10 \% \text { of respondents said ever, } 5 \% \text { said often and } \\
85 \% \text { said always. }\end{array}$ & $\begin{array}{l}10 \% \text { of respondents said ever, } 5 \% \text { said } \\
\text { often and } 85 \% \text { said always. }\end{array}$ \\
\hline $\begin{array}{l}\text { The "assessment" activity is carried out by absorbing } \\
\text { aspirations, coordinating and seizing opportunities both } \\
\text { internally and externally by involving teachers, the } \\
\text { workplace and parents. }\end{array}$ & $\begin{array}{l}10 \% \text { of respondents said ever, } 45 \% \text { said often and } \\
45 \% \text { said always. }\end{array}$ & $\begin{array}{l}40 \% \text { of respondents said often and } 60 \% \\
\text { said always }\end{array}$ \\
\hline $\begin{array}{l}\text { To further ensure that the skills developed are truly capable } \\
\text { of equipping students' skills to get ready for work, schools } \\
\text { prepare for this based on the school's resources such as } \\
\text { support for tools, funding and human resources. }\end{array}$ & $\begin{array}{l}5 \% \text { of respondents said ever, } 10 \% \text { said often and } \\
85 \% \text { said always }\end{array}$ & $\begin{array}{l}40 \% \text { of respondents said often and } 60 \% \\
\text { said always }\end{array}$ \\
\hline $\begin{array}{l}\text { For the sustainability of the skills program (life skill), the } \\
\text { school builds cooperation with other parties such as } \\
\text { companies, home industries or other institutions }\end{array}$ & $\begin{array}{l}5 \% \text { of respondents said never, } 75 \% \text { said ever, } \\
15 \% \text { said often and } 5 \% \text { said always }\end{array}$ & $\begin{array}{l}20 \% \text { of respondents said ever and } 20 \% \\
\text { said often and } 60 \% \text { said always }\end{array}$ \\
\hline \multicolumn{3}{|c|}{ Organizing } \\
\hline $\begin{array}{l}\text { Skills programs integrated in the curriculum require } \\
\text { organizing in the learning process }\end{array}$ & $90 \%$ of respondents agreed, $10 \%$ strongly agreed. & $\begin{array}{l}40 \% \text { of respondents agreed and } 60 \% \\
\text { strongly agreed. }\end{array}$ \\
\hline $\begin{array}{l}\text { Division of work between schools (educators and staffs), } \\
\text { government, parents and the workplace in the success of } \\
\text { skills programs for students with special needs }\end{array}$ & $\begin{array}{l}20 \% \text { of respondents said it was necessary, } 80 \% \\
\text { said it was highly necessary. }\end{array}$ & $\begin{array}{l}30 \% \text { of respondents said was necessary } \\
\text { and } 70 \% \text { said it was highly necessary. }\end{array}$ \\
\hline $\begin{array}{l}\text { The school distributes labor to educators and education } \\
\text { staff regarding their responsibilities related to the } \\
\text { implementation of skills programs (life skills) }\end{array}$ & $\begin{array}{l}5 \% \text { of respondents said it was conducted } \\
\text { occasionally, } 95 \% \text { said it was conducted. }\end{array}$ & $\begin{array}{l}20 \% \text { of respondents said it was conducted } \\
\text { occasionally and } 80 \% \text { said it was } \\
\text { conducted. }\end{array}$ \\
\hline $\begin{array}{l}\text { The existence of teachers who manage skills programs in } \\
\text { schools }\end{array}$ & $\begin{array}{l}95 \% \text { of respondents said there was, } 5 \% \text { said } \\
\text { always. }\end{array}$ & $\begin{array}{l}90 \% \text { of respondents said there was, } 10 \% \\
\text { said always. }\end{array}$ \\
\hline $\begin{array}{l}\text { The suitability of skills (life skills) developed with the } \\
\text { obstacles and needs of students }\end{array}$ & $\begin{array}{l}5 \% \text { of respondents said it was not appropriate, } \\
85 \% \text { said it was appropriate and } 10 \% \text { said it was } \\
\text { very appropriate }\end{array}$ & 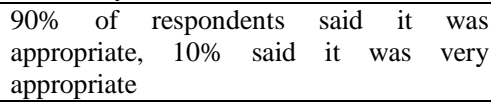 \\
\hline $\begin{array}{l}\text { The suitability of the skills program provided to students } \\
\text { with the needs in the world of work }\end{array}$ & $\begin{array}{l}70 \% \text { of respondents said it was appropriate, } 30 \% \\
\text { said it was very appropriate. }\end{array}$ & $\begin{array}{l}100 \% \text { of respondents said it was } \\
\text { appropriate. }\end{array}$ \\
\hline $\begin{array}{l}\text { The leadership (school) coordinates with all related parties } \\
\text { for the successful implementation of the skills program (life } \\
\text { skill) in schools }\end{array}$ & $45 \%$ of respondents said often. $55 \%$ said always. & $\begin{array}{l}10 \% \text { of respondents said it was rarely } \\
\text { conducted, } 70 \% \text { said often and } 20 \% \text { said } \\
\text { always. }\end{array}$ \\
\hline \multicolumn{3}{|l|}{ (2, } \\
\hline $\begin{array}{l}\text { The implementation of the skills program takes time thus } \\
\text { students really have practical life skills }\end{array}$ & $55 \%$ of respondents agreed, $45 \%$ strongly agreed & $\begin{array}{l}70 \% \text { of respondents expressed honesty and } \\
30 \% \text { who strongly agreed }\end{array}$ \\
\hline $\begin{array}{l}\text { In carrying out the learning process, especially in the skills } \\
\text { program for students with disability, a specific learning } \\
\text { model is needed }\end{array}$ & $\begin{array}{l}45 \% \text { of respondents agreed and 55\% strongly } \\
\text { agreed }\end{array}$ & $\begin{array}{l}40 \% \text { of respondents agreed and } 60 \% \\
\text { strongly agreed }\end{array}$ \\
\hline $\begin{array}{l}\text { Adjustment of learning media with the types of skills } \\
\text { programs organized for students with special needs. }\end{array}$ & $\begin{array}{l}10 \% \text { of respondents stated that it was not } \\
\text { appropriate, } 75 \% \text { stated that it was appropriate } \\
\text { and } 15 \% \text { stated that it was very appropriate. }\end{array}$ & $\begin{array}{l}70 \% \text { of respondents said it was appropriate } \\
\text { and } 30 \% \text { said it was very appropriate }\end{array}$ \\
\hline $\begin{array}{l}\text { Participation of students in skills programs used as } \\
\text { excellence in the school }\end{array}$ & $\begin{array}{l}5 \% \text { of respondents said they did not have to, } 5 \% \\
\text { said it was occasional and } 90 \% \text { said they had to } \\
\text { participate consistently }\end{array}$ & $\begin{array}{l}30 \% \text { of respondents said it was occasional } \\
\text { and } 70 \% \text { said they had to participate } \\
\text { consistently }\end{array}$ \\
\hline
\end{tabular}


TABLE I. Cont.

\begin{tabular}{|c|c|c|}
\hline Question & Private Special School (SLBS) & Public Special School (SLBN) \\
\hline $\begin{array}{l}\text { Cooperation among the schools, government, parents and } \\
\text { the workplace in the success of the skills program for } \\
\text { students with disability }\end{array}$ & $\begin{array}{l}5 \% \text { of respondents said they were never } \\
\text { synergistic, 5\% said they have been synergistic } \\
\text { and } 90 \% \text { of respondents said they were always } \\
\text { synergistic }\end{array}$ & $\begin{array}{l}5 \% \text { of respondents said they were never } \\
\text { synergistic, } 90 \% \text { said they have been } \\
\text { synergistic and 5\% said they were always } \\
\text { synergistic }\end{array}$ \\
\hline $\begin{array}{l}\text { Mastery of IT for students with special needs tailored to } \\
\text { their abilities in the midst of the current global trend }\end{array}$ & $\begin{array}{l}10 \% \text { of respondents said never, } 80 \% \text { said it was } \\
\text { given occasionally and } 10 \% \text { said it was often }\end{array}$ & $\begin{array}{l}10 \% \text { of respondents said it was given } \\
\text { occasionally, } 85 \% \text { said it was often and } \\
5 \% \text { said it was always }\end{array}$ \\
\hline $\begin{array}{l}\text { The percentage of school success is related to the } \\
\text { development and implementation of skills programs that } \\
\text { are the hallmarks of the school }\end{array}$ & $\begin{array}{l}60 \% \text { of respondents stated } 50 \% \text { success, } 20 \% \\
\text { stated the success rate was } 75 \% \text { and } 20 \% \text { stated } \\
\text { that their success was } 100 \%\end{array}$ & $\begin{array}{l}60 \% \text { of respondents stated } 50 \% \text { success, } \\
20 \% \text { of respondents stated the success rate } \\
\text { was } 75 \% \text { and } 20 \% \text { of respondents stated } \\
\text { that their success was } 100 \%\end{array}$ \\
\hline \multicolumn{3}{|c|}{ Evaluating } \\
\hline $\begin{array}{l}\text { Schools carry out life skills learning evaluations and } \\
\text { provide feedback }\end{array}$ & $\begin{array}{l}15 \% \text { of respondents said it was rarely conducted, } \\
75 \% \text { said it was frequent and } 10 \% \text { said it was } \\
\text { often }\end{array}$ & $\begin{array}{l}10 \% \text { of respondents said it was rarely } \\
\text { conducted and } 70 \% \text { said it was often }\end{array}$ \\
\hline tion in & $\begin{array}{l}\text { said it was correct and } 95 \% \\
\text { rect }\end{array}$ & $\begin{array}{l}80 \% \text { of } \mathrm{r} \\
20 \% \text { said }\end{array}$ \\
\hline $\begin{array}{l}\text { The evaluation of the school life skills program deliberately } \\
\text { provides a special time }\end{array}$ & $\begin{array}{l}15 \% \text { of respondents stated that the evaluation is } \\
\text { semester, } 15 \% \text { stated that it is monthly and } 70 \% \\
\text { stated that the evaluation is conducted weekly. }\end{array}$ & $\begin{array}{l}5 \% \text { of respondents said the evaluation is } \\
\text { carried out annually, 5\% stated that it is } \\
\text { semester, } 80 \% \text { said it is monthly and } 10 \% \\
\text { said the evaluation is carried out weekly. }\end{array}$ \\
\hline $\begin{array}{l}\text { Evaluation activities on life skills program carried out by } \\
\text { respondents ws that rarely, } 80 \% \text { continuous or sustainable } \\
\text { way }\end{array}$ & $\begin{array}{l}15 \% \text { of respondents said ever, } 70 \% \text { said often and } \\
15 \% \text { said always. }\end{array}$ & $\begin{array}{l}5 \% \text { of respondents said ever, } 85 \% \text { said } \\
\text { often and } 10 \% \text { said always. }\end{array}$ \\
\hline $\begin{array}{l}\text { Life skill learning evaluation is carried out thoroughly on } \\
\text { the aspects of attitude, knowledge and skills }\end{array}$ & $\begin{array}{l}10 \% \text { of respondents who stated occasionally, } \\
15 \% \text { stated often and } 75 \% \text { stated always }\end{array}$ & $\begin{array}{l}20 \% \text { of respondents stated occasionally, } \\
60 \% \text { said often and } 20 \% \text { said always }\end{array}$ \\
\hline $\begin{array}{l}\text { Evaluation of the implementation of life skills learning is } \\
\text { carried out democratically together between schools, the } \\
\text { business / industry and the government }\end{array}$ & $\begin{array}{l}85 \% \text { of respondents who stated rarely, } 5 \% \text { of } \\
\text { respondents who said often and } 10 \% \text { of } \\
\text { respondents who said always }\end{array}$ & $\begin{array}{l}15 \% \text { of respondents said it was rare, } 80 \% \\
\text { said it was frequent and } 5 \% \text { said always }\end{array}$ \\
\hline
\end{tabular}

TABLE II. Comparison between Private Special School (SLBS) ANd Public Special School (SLBN)

\begin{tabular}{|c|c|c|}
\hline $\begin{array}{r}\text { Question } \\
\end{array}$ & Public Special School & Private Special School \\
\hline $\begin{array}{l}\text { What steps should the school take thus the } \\
\text { given skills (life skills) match with the } \\
\text { students' abilities and practically have } \\
\text { financial value in the near future }\end{array}$ & $\begin{array}{l}\text { - Conduct an assessment of talents and interests. } \\
\text { Schools provide facilities and infrastructure } \\
\text { that support skills in accordance with the } \\
\text { results of the assessment } \\
\text { - Figure out the dynamics of the business world } \\
\text { among the students } \\
\text { - Before given skills, students were priorly } \\
\text { assessed } \\
\text { - Conduct an assessment towards the students' } \\
\text { abilities, conduct field surveys to determine } \\
\text { market needs and adjust their skills. } \\
\text { - Conduct more Exercises } \\
\text { Provide infrastructure, needed materials in } \\
\text { accordance with the students' talents } \\
\text { Learn life skills given by KPD students are } \\
\text { adjusted to the needs that must be performed } \\
\text { every day, for example culinary or cooking for } \\
\text { female students, and for male students as well. } \\
\text { - Assessment. } \\
\text { - Conduct first assessment towards the students' } \\
\text { potential. } \\
\text { Conduct an assessment and then develop their } \\
\text { abilities based on the results of the assessment. }\end{array}$ & $\begin{array}{l}\text { - Analyze the Perdirjen curriculum and adapt it to } \\
\text { the students' abilities and the current conditions of } \\
\text { society. } \\
\text { Conduct an assessment towards students according } \\
\text { to their abilities and interests. Moreover, it is } \\
\text { necessary to conduct cooperation with several } \\
\text { parties thus, students can immediately work after } \\
\text { graduate. } \\
\text { Provide practical learning, and test trials to } \\
\text { students. } \\
\text { Provide supporting facilities and infrastructure. } \\
\text { Participate in trainings on handicrafts, make } \\
\text { products which later can be used as provisions for } \\
\text { students with disability towards independence. } \\
\text { Provide a broad scope and provide direct or } \\
\text { practical training. } \\
\text { Provide training and practical test. } \\
\text { Creating a skills program (lifeskill) adjusted with } \\
\text { their abilities to face life in society }\end{array}$ \\
\hline $\begin{array}{l}\text { Life skills developed in the } \\
\text { interdependence program in the school, } \\
\text { whether it is conducted independently or } \\
\text { on the initiative of collaboration with } \\
\text { parties outside the school }\end{array}$ & $\begin{array}{l}\text { Sewing, culinary skills (making Bala-bala (a } \\
\text { vegetable fritter snack), souvenirs, accessories, } \\
\text { dolls from new and dowry, workshop, catfish } \\
\text { farming }\end{array}$ & $\begin{array}{l}\text { - Sewing, gardening / cooking. By holding these } \\
\text { activities, it is expected that the students will } \\
\text { become more independent and ready to face real } \\
\text { life. In addition, there are also activities organized } \\
\text { by related parties that support the independence of } \\
\text { the students. }\end{array}$ \\
\hline
\end{tabular}


TABLE II. Cont.

\begin{tabular}{|c|c|c|}
\hline Question & Public Special School & Private Special School \\
\hline $\begin{array}{l}\text { Efforts made when experiencing resource } \\
\text { constraints }\end{array}$ & $\begin{array}{l}\text { Establish partnerships with relevant } \\
\text { stakeholders, Looking for tutors from outside } \\
\text { the school to teach skills, If there are } \\
\text { constraints on costs, schools are looking for } \\
\text { volunteers, Conduct training for teachers, } \\
\text { collaborate with other parties, collaborate with } \\
\text { schools that organize inclusion, students who } \\
\text { are able and can communicate on } \\
\text { recommendations to SMK, In collaboration } \\
\text { with DUDI, the school will provide for these } \\
\text { shortages of resources, such as buying } \\
\text { materials or other necessities. }\end{array}$ & $\begin{array}{l}\text { - Schools seek funding independently from the } \\
\text { parents of students or by seeking funding sources } \\
\text { from willing volunteers. } \\
\text { - Cooperate with other parties. } \\
\text { - Coordinate proposals and cooperation with related } \\
\text { parties }\end{array}$ \\
\hline $\begin{array}{l}\text { The involved parties are related to the } \\
\text { implementation of life skills program at } \\
\text { school }\end{array}$ & $\begin{array}{l}\text { - } \quad \text { School committee, foundation. } \\
\text { - } \quad \text { Teachers, external tutors } \\
\text { - Professionals from outside } \\
\text { - } \quad \text { Private parties and related agencies } \\
\text { - } \quad \text { Up to now, it still cooperates with home tailors } \\
\text { - Social services (Dinsos) } \\
\text { - } \text { With some institutions such as SMK, PGRI, } \\
\text { and SMK Agro Bisnis Cikidang } \\
\text { - Social Affairs and Work Training Center } \\
\text { (BLK) } \\
\text { - DUDI } \\
\text { - } \quad \text { Workshop, home industry and others } \\
\text { - Parents and school committee }\end{array}$ & $\begin{array}{l}\text { - Community of parents, teachers and education } \\
\text { personnel in the school environment } \\
\text { - Job training agencies and companies (factories) } \\
\text { such as BLK, Dinsos, Pocari Sweat }\end{array}$ \\
\hline The ratio of teachers to students & • $1: 5$ & - $1: 6$ for a $50 \%$ success rate \\
\hline $\begin{array}{l}\text { how to define appropriate skills program } \\
\text { for all students }\end{array}$ & $\begin{array}{l}\text { - Sort according to the ability of each student } \\
\text { - } \quad \text { Skills are adjusted to the barriers of students } \\
\text { According to the skills and talents, according } \\
\text { to the conditions of the students' abilities and } \\
\text { parents support. } \\
\text { - Grouped competencies, process easiest skills } \\
\text { thus all students can understand }\end{array}$ & $\begin{array}{l}\text { - This begins with the results of the student } \\
\text { assessment and analysis of the selected skills } \\
\text { curriculum, from several selected skill choices that } \\
\text { most accommodate students according to the } \\
\text { assessment results. } \\
\text { - Provide direct training } \\
\text { - The skills program is adjusted to the ability of } \\
\text { students who make the completion program }\end{array}$ \\
\hline School strategy in dealing with obstacles & $\begin{array}{l}\text { - Lack of tutors on some vocational materials. } \\
\text { Appoint competent tutors from outside } \\
\text { - Budget and barriers owned by students } \\
\text { - Various students' abilities, } \\
\text { - The students receive weak concentration, } \\
\text { repeated until they can } \\
\text { - The obstacle is that the school must bring in } \\
\text { the experts }\end{array}$ & $\begin{array}{l}\text { - The obstacle faced is the limitation of special } \\
\text { teachers who are reliable in these skills. We are } \\
\text { coping with teacher self-learning available via the } \\
\text { internet } \\
\text { Lack of human resources and facilities. The } \\
\text { solution taken is maximizing existing human } \\
\text { resources and proposing facilities } \\
\text { With different characteristics, students must be } \\
\text { able to find the right way to handle each character } \\
\text { Constraints from resources and how to overcome } \\
\text { them by cooperating with related parties } \\
\text { Obstacles faced when the students face the } \\
\text { workplace after graduating from high school, } \\
\text { especially students with special mental needs, } \\
\text { schools cope with cooperation with other } \\
\text { institutions so that these children can be accepted } \\
\text { into the world of work even though it is not } \\
\text { optimal }\end{array}$ \\
\hline Life skills education time span & - 2 semester & - $1-2$ semester \\
\hline Learning model & $\begin{array}{l}\text { Demonstration video, quite appropriate, } \\
\text { students have to see it several times. The } \\
\text { medium is in the form of cooking tools, it is } \\
\text { very appropriate, Inpocus, cooking tools and } \\
\text { making cakes, money for making dowry, } \\
\text { stones for making stone dolls }\end{array}$ & $\begin{array}{l}\text { - Various include modeling, individual learning } \\
\text { models, learning by doing models, direct practice, } \\
\text { project base learning, culinary, practical learning } \\
\text { models }\end{array}$ \\
\hline
\end{tabular}


TABLE II. Cont.

\begin{tabular}{|c|c|c|}
\hline Question & Public Special School & Private Special School \\
\hline $\begin{array}{l}\text { What kinds of collaborations have } \\
\text { been / have / are being carried out } \\
\text { with the workplaces? how long has } \\
\text { this cooperation been running, and } \\
\text { are there any graduates who have } \\
\text { been / have been absorbed by the } \\
\text { DUDI partner? What are the } \\
\text { opportunities and obstacles faced? }\end{array}$ & $\begin{array}{l}\text { - Currently exploring cooperation with DUDI. } \\
\text { Nothing has been absorbed. Parents' barriers } \\
\text { are less supportive. Students are not willing } \\
\text { with various considerations we have the } \\
\text { Dipabel Berdikari foundation. the aim is to } \\
\text { record and accommodate the input for students } \\
\text { with disability who will be given various } \\
\text { trainings according to their abilities and } \\
\text { interests. we also accommodate the work of } \\
\text { students to market. we collaborate with DUDI } \\
\text { who are ready to accept / buy / order the work } \\
\text { of students } \\
\text { - Internships } \\
\text { Repairing, the chances are that students can } \\
\text { work in workshops that have collaborated, the } \\
\text { difficulty of directing students to communicate } \\
\text { well in the workplace. }\end{array}$ & $\begin{array}{l}\text { - There has ever been a collaboration with the local } \\
\text { district craft center, our products of botanical } \\
\text { gardening were sold there. However, due to a lack of } \\
\text { communication with related parties, the cooperation is } \\
\text { closed. } \\
\text { - Factory (garment). The obstacles that occur is } \\
\text { students do not feel cozy and thus resign } \\
\text { Perform cooperation by recruiting employees from } \\
\text { SLB graduates since the school was founded has } \\
\text { greater opportunities because students are already } \\
\text { experts in fields that are needed by the company. and } \\
\text { the only obstacle is lack of coordination with parents } \\
\text { of students through online media because not all } \\
\text { parents have online communication facilities } \\
\text { Recently it is still in form of cooperation with BLK } \\
\text { cooperation in recruiting graduate employees from } \\
\text { SLB schools, and the opportunity is very large } \\
\text { because it has enough experience in such fields. The } \\
\text { matter is only lack of coordination with the parents of } \\
\text { students } \\
\text { cooperation carried out by participating in a skills } \\
\text { training program for example skills training with } \\
\text { BPRSPAD Cibabat Bandung, graduates have been } \\
\text { absorbed in the KAHATEX company Bandung, the } \\
\text { opportunity to take part in this training program every } \\
\text { year and the obstacles for mental retardation students } \\
\text { are still rarely absorbed in the training due to the } \\
\text { limited quota of students for training }\end{array}$ \\
\hline $\begin{array}{l}\text { The feedback obtained from the } \\
\text { evaluation of skills programs to } \\
\text { improve life skills learning for the } \\
\text { next students with special needs }\end{array}$ & $\begin{array}{l}\text { - Improve the input of human resources in order } \\
\text { to dominate and compete } \\
\text { - } \quad \text { Provide flexibility for students to choose the } \\
\text { skills they enjoy } \\
\text { - } \quad \text { Organize improvements and enrichments } \\
\text { Teachers for ABK students must have certain } \\
\text { skills and expertise as capital for learning life } \\
\text { skills } \\
\text { - Simplification of the program }\end{array}$ & $\begin{array}{l}\text { - The feedback obtained includes new methods and } \\
\text { new media } \\
\text { - learning methods } \\
\text { carry out direct learning with a predetermined time } \\
\text { and that the educator participants can afford } \\
\text { - } \quad \text { obtain sufficient resources } \\
\text { Lifeskill for students with disability is self-provision } \\
\text { thus students are ready when they leave school }\end{array}$ \\
\hline $\begin{array}{l}\text { essential things need to conduct in } \\
\text { evaluating life skill learning for } \\
\text { students with special needs }\end{array}$ & $\begin{array}{l}\text { - Need to pay attention to the ability of PD } \\
\text { students who are not able to master and } \\
\text { compete } \\
\text { continuously performed and focus on areas of } \\
\text { interest to students. The teacher must be } \\
\text { resilient and painstaking } \\
\text { - Achievement of competencies } \\
\text { - The suitability between the life skills given } \\
\text { and the evaluations given }\end{array}$ & $\begin{array}{l}\text { - Evaluation through practice must be independently } \\
\text { able to describe the abilities of students } \\
\text { - Learning methods } \\
\text { - } \quad \text { very accurate and thorough monitoring } \\
\text { - Percentage of labor absorption by companies } \\
\text { Must stay focused and patient, and improve the } \\
\text { abilities contained in each student }\end{array}$ \\
\hline $\begin{array}{l}\text { What aspirations were obtained } \\
\text { from these parties to enhance the } \\
\text { effectiveness of implementing the } \\
\text { skills program (life skills) }\end{array}$ & $\begin{array}{l}\text { - Motivate teachers to be able to create skills } \\
\text { according to their abilities and necessities } \\
\text { - } \quad \text { Life skills program to make it more diverse } \\
\text { - } \quad \text { Conduct independent training } \\
\text { interest to students. Parents must be proactive } \\
\text { with school programs. The community must } \\
\text { respect and accept the students as they are. } \\
\text { DUDI can play an active role in recruiting } \\
\text { students with disability. } \\
\text { - Prioritizing local content skills } \\
\text { - }\end{array}$ & $\begin{array}{l}\text { - Feedback that makes Cullinary art products better } \\
\text { - In addition to training the skills of students, schools } \\
\text { must also train or mentally prepare students who will } \\
\text { enter the workplace so that they do not easily } \\
\text { discouraged } \\
\text { - Aspirations of commitment in time to more } \\
\text { thoroughly conduct practical trials } \\
\text { - Provision of capital / funds and facilities } \\
\text { - By giving the opportunity to the crew members to } \\
\text { take part } \\
\text { - Willing to make students become experts in exploring } \\
\text { life skills at school and outside of school later } \\
\text { The results of the training program have been } \\
\text { effective. This can be seen from the achievement of } \\
\text { the results of the training program competency test } \\
\text { related to increasing knowledge (cognitive), attitudes } \\
\text { (affective) and skills (psychomotor) received by } \\
\text { participants after completing the training program. }\end{array}$ \\
\hline
\end{tabular}


Based on results obtained in this line of research, what really stands out is that in both schools, whether SLBN or SLBS have the same issues, namely the absence of the same understanding among various policies, planning, organizing, actuating and evaluations that have been implemented, this is evidenced by the existence of various perceptions with different percentages, little or much of that percentage, it still shows a difference of perspective and understanding. Meanwhile, in management, most importantly, all academicians have the same purposes [7].

As well, the implementation of life skills management in SLBN and SLBS is almost as the same as implementing the management functions to achieve the identical purposes, such as graduates have independent competence and are able to solve their life problems, similarly stated by Ghunu and Meirawan [8] that the role of the principal to equalize the perception of the goals of his/her subordinates will be able to implement the success of the management. Likewise, the differences between the two schools are related to the differences owned by the components of education, including: Lucas [9] stated that policy and politics will play a role in changing the colour of other components such as educators and education staff, students, facilities and infrastructure, education costs, curriculum, and other components.

And therefore, there is now considerable evidence that the success of life skills education for children with special needs, requires professional management and management to employ all the resources owned by the school to be utilized and used optimally and efficiently with high beneficial values, and thus graduates from special schools both public and private have the spirit of life community.

\section{CONCLUSION}

This report presented the conclusion of research that the difference in the implementation of life skills education management for students with disability requires professional guidance from teachers with the excellent skills and appropriate learning strategies by using the existing resources to optimize their usefulness thus graduates are in accordance with the formulated objectives, such as having independent living and achieving economic independence and in turns they are no longer considered as a burden to others. By way of conclusion, the only matter that must be conducted is to build the similar viewpoints among academics concerning understanding policies, objectives, curriculum, duties and functions and empowerment of other components, which triggers the success of teaching-learning processes in special educational settings organised for students with disability.

\section{ACKNOWLEDGMENT}

This paper is one of the research outputs that funded by the Graduate School of the Indonesian University of Education in the Indonesian University of Education Postgraduate School research grant of the year 2020. The research team would like to thank all parties, namely Postgraduate School of the Indonesian University of Education, respondents and other parties who have contributed their time and commitment to this research, so that it becomes the result of research that can be accounted for

\section{REFERENCES}

[1] R. Shyam and D. Govil, "Stress and Family Burden in Mothers of Children with Disabilities," Int. J. Interdiscip. Multidiscip. Stud., vol. 1, no. 4, pp. 152-159, 2014.

[2] I.D. Aprilia, J. Permana, and E. Prihatin, "Life Skill Educationa Management Based on Vocational for Students with Disabilities to be Ready for Work," 2nd International Conference on Research of Educational Administration and Management (ICREAM 2018), vol. 258, no. Icream 2018, pp. 134-138, 2019.

[3] C. Granados Beltrán, "A framework for the construction of academic communities," Rev. Folios, no. 30, p. 39, 2017

[4] H.R. Afsaneh, J. Gunnel, W. Suzanne, and L.H. Kajsa, "Time management skills in relation to general self-efficacy and parental sense of competence in individuals with and without cognitive disabilities,' Cogent Psychol., vol. 6, no. 1, 2019.

[5] L. Donnellan and E.S. Mathews, "Service providers' perspectives on life skills and deaf and hard of hearing students with and without additional disabilities: transitioning to independent living," Eur. J. Spec. Needs Educ., vol. 00, no. 00, pp. 1-15, 2020

[6] D. Olson, "It's Off to Work We Go: Attitude Toward Disability a Vocational Training Programs at Jewish Summer Camps,” J. Jewish Educ., vol. 83, no. 1, pp. 27-48, 2017.

[7] E. Prihatin, D. Meirawan, A. Suryana, R. IZFS, and A. Komariah, "Synchronization of Strategic Plan and Implementation in Legal Entity State University through Good University Governance," Int. J. Psychosoc. Rehabil., vol. 24, no. 04, pp. 2442-2458, 2020.

[8] E.P. Ghunu and Meirawan, "How Indonesiaan Principals create and improve teachers self efficiency," Int. J. Innov. Creat. Chang., vol. 5, no. 3, pp. 685-707, 2019

[9] C.J. Lucas, "The Foundations Of Education Component In State Regulations Governing Teacher Preparation And Initial Certification," Educational Studies, vol. 10, no. 1, pp. 1-29, 1979 